\title{
Perancangan Enterprise Architecture Sistem Informasi Terminal Menggunakan Model TOGAF ADM (Studi Kasus: Terminal Tipe B Palabuhanratu)
}

\author{
Risa Sri Marlianti ${ }^{*}$, Sudin Saepudin ${ }^{2}$ \\ 1,2Program Studi Sistem Informasi, Universitas Nusa Putra, Sukabumi, Jawa Barat \\ Email: ${ }^{1 *}$ risa.sri_si17@nusaputra.ac.id, ${ }^{2}$ Sudin.saepudin@ @usaputra.ac.id
}

(Naskah masuk: 23 Mei 2021, direvisi: 24 Jun 2021, diterima: 28 Jun 2021)

\begin{abstract}
Abstrak
Terminal Palabuhanratu merupakan terminal penumpang tipe B yang merupakan terminal utama terbesar di kawasan Sukabumi bagian selatan. Terminal ini terletak di Jalan Pasar Palabuhanratu, Desa Palabuhanratu, Kecamatan Palabuhanratu, Kabupaten Sukabumi. Terminal yang dikelola oleh Dinas Perhubungan Provinsi Jawa Barat ini menyediakan pelayanan angkutan Mobil Penumpang Umum (MPU), angkutan perintis, dan angkutan antar kota. Pengelola Terminal Tipe B Palabuhanratu belum mengimplementasikan Enterprise Architecture (EA) untuk menyelaraskan strategi SI/TI dengan strategi bisnisnya. Dalam implementasinya, pihak pengelola Terminal Tipe B Palabuhanratu memberikan pelayanan informasi dengan baik kepada calon penumpang, walaupun belum terstruktur secara sistematis dalam penerapan perancangan SI/TI sehingga proses pelayanan untuk kegiatan bisnis belum berjalan secara maksimal. Umumnya dalam memberikan informasi layanan transportasi mengenai waktu pemberangkatan, rute tujuan, tarif, dan pengaduan. Penelitian ini bertujuan untuk membuat sebuah Perancangan Enterprise Architecture untuk pengelolaan layanan transportasi dan pelayanan pengaduan di Terminal Tipe B Palabuhanratu dengan menggunakan model TOGAF ADM dan akan menghasilkan sebuah blue print yang nantinya dapat digunakan sebagai acuan dalam mengimplementasikan pembuatan sistem, sehingga pengelola terminal dapat dengan mudah memberikan informasi dan dapat meningkatkan pelayanan di Terminal Tipe B Palabuhanratu. Metode penelitian ini menggunakan model TOGAF Architecture Development Method (ADM) untuk mendukung Perancangan Enterprise Architecture Sistem Terminal Tipe B Palabuhanratu.
\end{abstract}

Kata Kunci: Perancangan Enterprise Architecture, Sistem Informasi Terminal, TOGAF (ADM)

\section{Enterprise Architecture Design of Terminal Information System Using TOGAF ADM Model (Case Study: Palabuhanratu Type B Terminal)}

\begin{abstract}
Palabuhanratu Terminal is a type B passenger terminal which is the largest main terminal in the south Sukabumi area. This terminal is located on Jalan Pasar Palabuhanratu, Palabuhanratu Village, Palabuhanratu District, Sukabumi Regency. The terminal, which is managed by the Transportation Service of West Java Province, provides public passenger car (MPU) transportation services, pioneer transportation, and inter-city transportation. The manager of the Palabuhanratu Type B Terminal has not implemented Enterprise Architecture (EA) to align the IS/IT strategy with its business strategy. In its implementation, the manager of Terminal Type B Palabuhanratu in providing good information services to prospective passengers, although it has not been structured systematically in the application of IS/IT design, so that the service process for business activities has not run optimally. Generally in providing information on transportation services regarding departure times, destination routes, fare,s and complaints. This study aims to create an Enterprise Architecture Design for the management of transportation services and complaint services at Type B Terminal Palabuhanratu using the TOGAF ADM model and will produce a blue print which can later be used as a reference in implementing the system creation, so that terminal managers can easily in provide information and can improve services at Terminal Type B Palabuhanratu. This research method uses the
\end{abstract}


TOGAF Architecture Development Method (ADM) model to support the Enterprise Architecture Design of the Palabuhanratu Type B Terminal system.

Keywords: Enterprise Architecture Design, Terminal Information System, TOGAF (ADM)

\section{PENDAHULUAN}

Terminal adalah salah satu komponen dari sistem transportasi yang mempunyai fungsi utama sebagai tempat pemberhentian sementara kendaraan umum untuk menaikkan dan menurunkan penumpang dan barang hingga sampai ke tujuan akhir suatu perjalanan [1]. Terminal Palabuhanratu merupakan sebuah terminal penumpang tipe B, yang merupakan terminal induk terbesar dikawasan Sukabumi Selatan. Terminal ini terletak di jalan pasar Palabuhanratu, Desa Palabuhanratu, Kecamatan Palabuhanratu, Kabupaten Sukabumi. Terminal yang dikelola oleh Dinas Perhubungan Provinsi Jawa Barat ini menyediakan pelayanan transportasi Mobil Penumpang Umum (MPU), angkutan perintis, dan angkutan antar kota.

Minimnya pemanfaatan teknologi pada Terminal Palabuhanratu membuat pengelola terminal terbatas dalam memberikan informasi kepada masyarakat atau calon penumpang. Umumnya infomasi layanan transportasi mengenai jadwal, rute, tarif, dan layanan pengaduan. Pengelola Terminal Tipe B Palabuhanratu belum menerapkan Enterprise Architecture (EA) untuk menyelaraskan strategi SI/TI dengan strategi bisnisnya. Dalam pelaksanaannya pengelola Terminal Tipe B Palabuhanratu memberikan layanan informasi dengan baik kepada calon penumpang, walaupun belum terstrukturnya sistematis dalam penerapan perancangan SI/TI sehingga pelayanan proses aktivitas bisnis belum berjalan secara optimal, dimana pengelola Terminal Tipe B Palabuhanratu memberikan informasi layanan transportasi masih menggunakan papan pengumuman pada area terminal. Oleh karena itu calon penumpang terbatas dalam mendapatkan pelayanan informasi di Terminal Tipe B Palabuhanratu.

Terdapat grafik data jumlah penumpang pada Terminal Tipe B Palabuhanratu dimana tercatat dari tahun 2018 s/d 2019 adanya peningkatan jumlah penumpang datang dan penumpang berangkat. Adapun tahun 2020 ada penurunan jumlah penumpang datang dan penumpang berangkat di Terminal Tipe B Palabuhanratu karena adanya pengurangan jumlah transportasi dan jumlah penumpang.

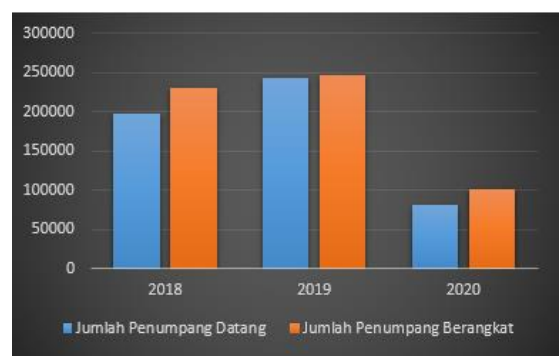

Gambar 1. Jumlah Penumpang Datang dan Berangkat
Berdasarkan masalah yang telah dipaparkan di atas, maka dibutuhkan suatu perancangan arsitektur enterprise untuk pengelolaan layanan transportasi mengenai jadwal, tarif, rute, dan layanan pengaduan pada Terminal Tipe B Palabuhanratu dengan menggunakan model TOGAF ADM, yang akan menghasilkan sebuah kerangka kerja TOGAF atau blueprint sehingga nantinya dapat dijadikan sebagai acuan dalam pengimplementasian pembuatan sistem untuk meningkatkan pelayanan informasi pada Terminal Tipe B Palabuhanratu.

\section{LANDASAN TEORI}

A. Arsitektur Enterpirse

Arsitektur enterprise memiliki dua pengertian, yang pertama adalah model komposisi untuk merencanakan struktur bisnis luar dan dalam (melalui aktivitas bisnis) dan memberikan penentuan yang masuk akal tentang bagaimana beberapa aktivitas dan proyek harus mengeksploitasi inovasi data (sebagai aturan, secara eksplisit, kerangka data desain dan inovasi data). Kedua, ini adalah komponen seperti lingkungan arsitektur, dan mengatur perubahan untuk membantu, memfasilitasi, dan mengatur semua bagian bisnis, menjamin semuanya mengarah pada tujuan yang sama. [2]

\section{B. TOGAF Architecture Development Method (ADM)}

The Open Group Architecture Framework (TOGAF) adalah kerangka arsitektur yang terperinci dan sekumpulan alat (tools) pendukung untuk mendorong dalam arsitektur enterprise. Komponen penting dari TOGAF adalah ADM yang memberikan garis besar khusus untuk proses peningkatan EA. Architecture Development Method dapat dilihat dengan penggambaran siklus yang terdiri dari sembilan langkah proses [3]. Adapun fase TOGAF ADM sebagai berikut:

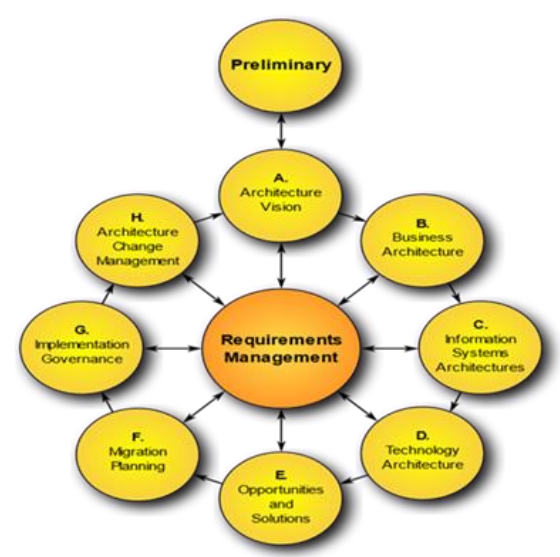

Gambar 2. TOGAF ADM 


\section{Value Chain}

Value chain adalah siklus dimana sebuah organisasi mengidentifikasi kegiatan utama dan tambahan yang meningkatkan item, kemudian memeriksanya untuk mengurangi biaya atau peningkatan diferensiasi [4]. Chain:

Berikut adalah gambaran model dari Porter's Value

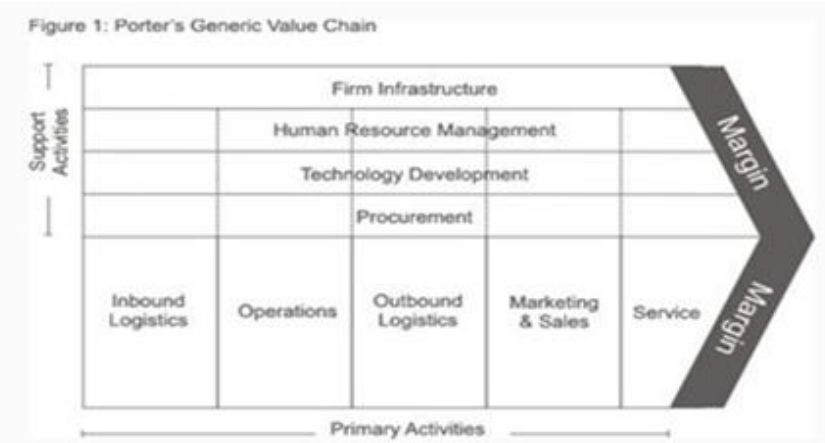

Gambar 3. Value Chain

\section{METODOLOGI PENELITIAN}

\section{A. Langkah-langkah Penelitian}

Pada penelitian ini penulis menerapkan metode arsitektur TOGAF ADM, yang terdiri dari 10 fase. Namun dalam penerapan penelitian ini hanya beberapa fase yang akan diterapkan sesuai dengan kebutuhan perancangan Sistem Informasi Terminal Palabuhanratu diantaranya: Preliminary Phase, Architecture Vision, Business Architecture, Information Systems Architectures, Technology Architecture, Requirements Management, yang akan dijelaskan sebagai berikut:

\section{Preliminary Phase}

Fase ini merupakan tahapan awal yang merupakan persiapan arsitektur enterprise dan menentukan ruang lingkup arsitektur yang akan dikembangkan. Maka hal yang harus dijabarkan diantaranya, menentukan prinsip-prinsip sebagai acun pengembangan architecture (Principal Catalog) dan mengidentifikasi $5 \mathrm{~W}+1 \mathrm{H}$.

\section{Requirements Management}

Pada fase ini mempunyai tujuan untuk menentukan kebutuhan arsitektur dalam perancangan sistem informasi termilanal tipe B Palabuhanratu. Tahapan yang dilakukan:

a) Core Business

b) Issue Organisasi

c) Solusi Bisnis

\section{Architecture Vision}

Pada fase ini merupakan fase inisiasi dari siklus pengembangan arsitektur yang mencakup pendefinisian ruang lingkup, dan pengajuan persetujuan untuk memulai pengembangan arsitektur. Adapun kebutuhan yang akan dijelaskan pada tahapan ini antara lain dengan memahami kunci utama arsitektur vision yang isinya adalah: a) Pendefinisian visi dan misi.

b) Menentukan tujuan pembuatan perencanaan arsitekstur Sistem Informasi Terminal Tipe B Palabuhanratu.

c) Pendefinisian Struktur Organisasi dan Tupoksinya

\section{Business Architecture}

Pada fase ini adalah menganalisis aktivitas bisnis saat ini di terminal tipe B Palabuhanratu, bertujuan untuk mengembangkan arsitektur bisnis untuk mendukung visi arsitektur dan melakukan pemodelan arsitektur yang di inginkan.

a) Identifikasi aktivitas bisnis saat ini di Terminal Tipe B Palabuhanratu.

b) Merancang arsitektur aktivitas bisnis yang di usulkan dengan menggunakan model usecase

\section{Information System Architecture}

Pada fase ini yaitu membahas pengembangan arsitektur data dan arsitektur aplikasi sesuai yang diinginkan dan menekankan bagaimana arsitektur sistem informasi dibangun meliputi arsitektur data dan arsitektur aplikasi yang akan digunakan oleh Terminal Palabuhanratu.

\section{Technology Architecture}

Fase ini berguna untuk mendefinisikan arsitektur teknologi untuk mendukung arsitektur sistem informasi yang dibutuhkan. Untuk membangun arsitektur teknologi dibutuhkan tahapan sebagai berikut:

a) Arsitektur Jaringan

b) Platform teknologi.

c) Spesifikasi perangkat lunak dan perangkat keras yang diperlukan.

\section{B. Pengumpulan Data}

1. Observasi

Observasi merupakan suatu strategi yang tepat dan eksplisit dalam mengumpulkan informasi dan mempunyai arti mengumpulkan data untuk digunakan sebagai objek kajian dalam suatu penelitian. [5]

Adapun observasi dilakukan untuk meninjau secara langsung kegiatan yang ada pada Terminal Tipe B Palabuhanratu yang terletak di Jl. Raya Pangsor Palabuhanratu, Kecamatan Palabuhanratu.

\section{Wawancara}

Wawancara adalah pertemuan yang dipimpin oleh dua individu untuk bertukar informasi atau pemikiran melalui tanya jawab, dengan tujuan agar cenderung diturunkan ke keputusan atau signifikansi dalam topik tertentu. [6]

Adapun wawancara dilakukan untuk mencari dan mengumpulkan data dengan cara bertanya langsung dengan pengelola aktivitas di terminal, mengenai data jumlah penumpang, layanan transportasi mengenai jadwal, rute, tarif dan data lainnya yang diperlukan.

3. Studi Pustaka

Studi Pustaka digunakan untuk memudahkan peneliti mencari dan mengumpulkan informasi yang relevan 
menggunakan teori-teori yang akan digunakan dalam proses membuat penelitian. Informasi tersebut dapat diperoleh dari berbagai sumber seperti karya ilmiah, buku-buku, dan sumber-sumber lain. [7].

\section{Rencana Analisis Sistem}

Menurut Rosa A.S dan M.Shalahuddin menyatakan bahwa Unified Modeling Languange (UML) adalah salah standar bahasa yang banyak digunakan di dunia industri untuk mendefinisikan requirement, membuat analisis \& desain, serta menggambarkan arsitektur dalam pemrograman berorientasi objek [8]. Diagram UML yang akan dijabarkan adalah:

\section{Use Case Diagram}

Menurut Murad, "Diagram use case adalah diagram yang bersifat status yang memperlihatkan himpunan use case dan aktor-aktor (suatu jenis khusus dari kelas" [9].

\section{Activity Diagram}

Menurut Sukamto dan M. Shalahuddin, diagram aktivitas atau activity diagram menggambarkan aliran kerja atau aktivitas dari sebuah sistem atau proses bisnis atau menu yang ada pada perangkat lunak [10].

\section{HASIL DAN PEMBAHASAN}

\subsection{Hasil Pemaparan Model TOGAF}

\section{Preliminary Phase}

Tahapan ini mendefinisikan mengenai prinsip-prinsip arsitektur dan identifikasi $5 \mathrm{~W}+1 \mathrm{H}$. Berikut Tabel Prinsipprinsip Arsitektur dan Identifikasi $5 \mathrm{~W}+1 \mathrm{H}$ :

\section{a. Prinsip Arsitektur}

Prinsip-prinsip ini membantu dalam proses pemilihan arsitektur yang akan digunakan dalam perancangan sistem, sebagaimana pada Tabel 1 di bawah ini.

Tabel 1. Principle Catalog

\begin{tabular}{|c|c|c|}
\hline No & $\begin{array}{c}\text { Prinsip-Prinsip } \\
\text { Arsitektur } \\
\end{array}$ & Tujuan \\
\hline 1. & \multicolumn{2}{|c|}{ Prinsip Bisnis } \\
\hline & $\begin{array}{l}\text { Arsitektur yang dibuat } \\
\text { harus sesuai dengan } \\
\text { tujuan dalam aktivitas } \\
\text { bisnis pada Terminal } \\
\text { Tipe B Palabuhanratu }\end{array}$ & $\begin{array}{l}\text { - } \text { Mendukung dalam } \\
\text { proses bisnis di Terminal } \\
\text { Tipe B Palabuhanratu } \\
\text { - Mendukung dalam } \\
\text { meningkatkan pelayanan }\end{array}$ \\
\hline 2. & \multicolumn{2}{|c|}{ Prinsip Aplikasi } \\
\hline & $\begin{array}{l}\text { Dalam perancangan } \\
\text { arsitektur Aplikasi, } \\
\text { sistem harus Mudah } \\
\text { digunankan oleh user } \\
\text { dan mudah dalam } \\
\text { pengembangan sistem }\end{array}$ & $\begin{array}{l}\text { Kemudahan dalam } \\
\text { penggunaan aplikasi dapat } \\
\text { meningkatkan ektifitas } \\
\text { proses bisnis. }\end{array}$ \\
\hline 3. & \multicolumn{2}{|c|}{ Prinsip Data } \\
\hline
\end{tabular}

\begin{tabular}{ll}
\hline $\begin{array}{l}\text { Arsitektur Data harus } \\
\text { Aman dan mudah di } \\
\text { akses }\end{array}$ & $\begin{array}{l}\text { Data (informasi) dan sistem } \\
\text { harus terlindungi dan data } \\
\text { harus mudah diakses ketika } \\
\text { diperlukan }\end{array}$ \\
\hline $4 . \quad$ Prinsip Data \\
\hline & Independensi Tekologi \\
& $\begin{array}{l}\text { Menggunakan software, } \\
\text { hardware, dan platfrom } \\
\text { untuk mencegah data yang } \\
\text { tidak kompatibel }\end{array}$ \\
\hline
\end{tabular}

b. Identifikasi $5 \mathrm{~W}+1 \mathrm{H}$

Identifikasi $5 \mathrm{~W}+1 \mathrm{H}$ bertujuan untuk menjelaskan objek yang terkait dengan Terminal Tipe B Palabuhanratu, dapat dilihat pada Tabel 2 .

Tabel 2. Identifikasi $5 \mathrm{~W}+1 \mathrm{H}$

\begin{tabular}{lll}
\hline No & Identifikasi & \multicolumn{1}{c}{ Objek dan Deskripsi } \\
\hline 1 & What & $\begin{array}{l}\text { Objek: } \\
\text { Lingkup Arsitektur }\end{array}$
\end{tabular}

Deskripsi:

Pembuatan Perancangan Enterprise

Architecture Terminal Tipe B

Palabuahanratu menggunakan model

TOGAF, yang menghasilkan

perancangan berupa layanan

transportasi mengenai jadwal, tarif, rute, dan layanan pengaduan.

\begin{tabular}{lll}
\hline 2 Who & Objek: \\
& Siapakah yang membuat Perancangan \\
& Enterprise Architecture Sistem \\
& Informasi Terminal? \\
& \\
& \\
& Deskripsi: \\
& Peneliti studi kasus \\
\hline 3 & Where & Objek: \\
& & Dimanakah penelitian ini dilakukan?
\end{tabular}

Deskripsi:

Penelitian ini dilakukan di Terminal

Tipe B Palabuhanratu. Jln Raya

Pangsor Palabuhanratu

\begin{tabular}{lll}
\hline 4 When & Objek: \\
& Kapankah waktu penyelesaian \\
& perancangan ini? \\
& Deskripsi: \\
& Pada Mei-Juli 2021 \\
& Objek: \\
& Mengapa membuat perancangan \\
& Enterprise Arhitecture Sistem \\
& Informasi Terminal ? \\
& Deskripsi: \\
& Untuk membantu pengelolaan \\
& Terminal Tipe B Palabuhanratu dalam \\
& menyelaraskan strategis SI/TI dengan \\
\hline
\end{tabular}




\begin{tabular}{ll}
\hline & strategi bisnisnya. Sehingga \\
memepermudah dalam memberikan & informasi dan dapat meningkatkan \\
pelayanan. khususnya pelayanan & transportasi mengenai informasi \\
& jadwal, tarif, rute, dan layanan \\
pengaduan, sehingga nantinya dapat \\
di jadikan sebagai acuan dalam \\
implementasi pembuatan sistem. \\
Objek: \\
Bagaimana melakukan proses \\
Perancangan Enterprise Architecture \\
Sistem Informasi Terminal di \\
Terminal Tipe B Palabuhanratu? \\
\\
Deskripsi: \\
Memanfaatkan kerangka kerja \\
TOGAF dengan menrapkan beberapa \\
Fase TOGAF ADM dalam \\
perancangan EA Terminal Tipe B \\
Palabuhanratu
\end{tabular}

\section{Requiremnets Management}

a. Core Bisnis (Aktifitas Bisnis Utama)

Aktifitas utama bisnis pada Terminal Tipe B Palabuhanratu yaitu menyediakan pelayanan trasportasi mengenai jadwal, rute, tarif dan layanan pengaduan. Penerapan perancangan SI/TI yang dapat di jadikan sebagai acuan dalam implementasi pembuatan sistem, seperti:

1) Pemanfaatan teknologi informasi dapat memudahkan pengelola dalam penyampaian informasi.

2) Meningkatkan pelayanan terhadap calon penumpang.

b. Issue Organisasi

Dari hasil observasi serta analisis terhadap proses bisnis dan aktivitas di Terminal Tipe B Palabuhanratu diperoleh gambaran permasalahan yang ada di terminal, permasalahan tersebut yaitu:

1) Kurangnya pemanfaatan teknologi informasi dalam proses penyampaian informasi.

2) Selama ini proses penyampaian informasi masih di lakukan dengan memasang papan pengumuman dan memanfaatkan pengarah suara sebagai sarana informasi di Terminal Tipe B Palabuhanratu.

3) Kurang maksimalnya pelayanan yang diberikan pihak pengelola terminal.

c. Solusi Bisnis

Adapun solusi bisnis terhadap permasalahan yang ada yaitu dapat dilihat pada tabel 3 sebagai berikut:

Tabel 3. Solusi Bisnis

\begin{tabular}{lcc}
\hline No & Permasalahan & \multicolumn{1}{c}{ Saran Perbaikan } \\
\hline 1. & $\begin{array}{l}\text { Sarana Penyampaian } \\
\text { Informasi }\end{array}$ & $\begin{array}{l}\text { Menyediakan SI/TI yang } \\
\text { mendukung dalam } \\
\text { penyampaian informasi }\end{array}$ \\
\hline
\end{tabular}

\begin{tabular}{lll}
\hline 2. & Kurang Maksimal & Untuk meningkatkan \\
Pelayanan Pengelola & pelayanan di terminal \\
Terminal & pengelola menyediakan \\
& layanan trasportasi \\
& mengenai info jadwal, tarif, \\
& rute, layanan pengaduan, \\
& dan informasi lainnya \\
& seputar Terminal Tipe B \\
& Palabuhanratu \\
\hline
\end{tabular}

\section{Architecture Vision}

a. Pendefinisian Visi Misi

Visi dibuat oleh Terminal Tipe B Palabuhanratu adalah "Terwujudnya pelayanan transportasi yang handal, tertib, dan berdaya saing nasional, dengan angkutan publik sebagai layanan utama". Adapun penjabaran mengenai Misi Terminal Tipe B Palabuhanratu yaitu:

1) Mewujudkan layanan transportasi yang selamat, lancar, aman, dan terintegrasi.

2) Mewujudkan layanan transportasi yang informatif berbasis teknologi informasi dan komunikasi.

3) Mewujudkan transportasi ramah lingkungan dan menunjang aksesibilitas bagi penyandang disabillitas.

4) Mewujudkan biaya transportasi yang terjangkau bagi masyarakat

\section{b. Tujuan Organisasi}

Tujuan dari pencapaian visi dan misi di Terminal Tipe B

Palabuhanratu memiliki beberapa tujuan sebagai berikut:

1) Untuk meningkatkan layanan transportasi

2) Terwujdnya layanan transportasi dengan memanfaatkan teknologi informasi

3) Biaya yang terjangkau bagi masyarakat.

c. Struktur Organisasi

Berikut Merupakan struktur organisasi di Terminal Tipe B Palabuhanratu. Dilihat pada Gambar 4 di bawah ini.

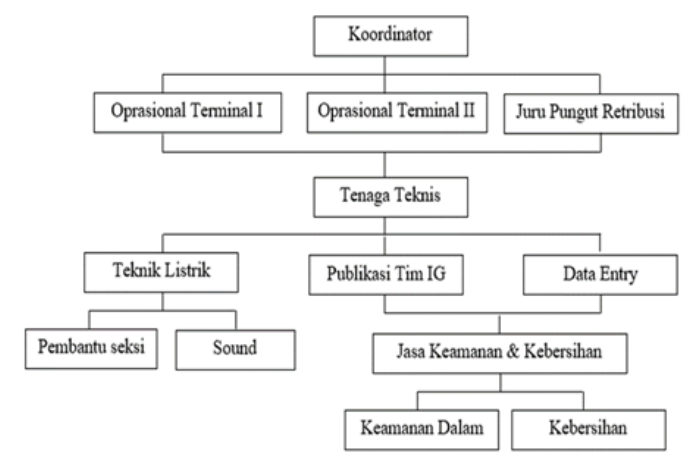

Gambar 4. Struktur Organisasi

\section{d. Analisis Value Chain}

Menganalisis seluruh proses kerja di Terminal Tipe B Palabuhanratu dengan menggunakankan analisis Value Chain yang bertujuan untuk memetakan seluruh proses kerja yang terjadi dalam organisasi. Adapun kategori aktivitas dibagi 
menjadi dua yaitu aktivitas utama dan aktivitas pendukung, seperti pada Gambar 5 di bawah ini.

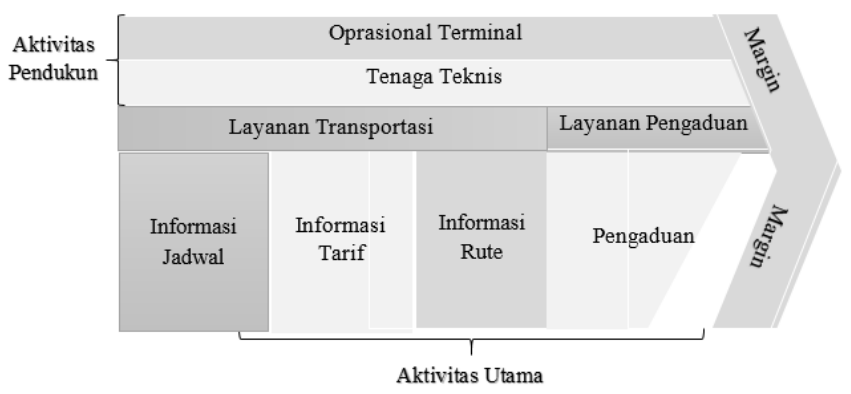

Gambar 5. Analisis Value Chain

\section{e. Aktivitas Utama}

Aktivitas utama yang termasuk kedalam analisis Value Chain, berikut merupakan rincian aktivitasnya:

1) Layanan Trasportasi

a. Jadwal

Memberikan informasi mengenai jadwal keberangkatan transportasi di Terminal Tipe B Palabuhanratu. Berikut jadwal Transportasi di Terminal Tipe B Palabuhanratu.

- Jadwal bus dari Terminal Tipe B Palabuhanratu diantaranya jurusan Palabuhanratu - Bogor, Palabuhanratu - Sukabumi.

- Jadwal Damri dari Terminal Tipe B Palabuhanratu diantaranya jurusan Palabuhanratu - Sagaranten, Palabuhanratu - Cikidang, Palabuhanratu Cileungsing.

- Jadwal Elf dari Terminal Tipe B Palabuhanratu diantaranya, Palabuhanratu - Cikotok, Palabuhanratu - Binuangeun, Palabuhanratu Pasir Kuray.

b. Rute

Memberikan informasi mengenai rute tujuan transportasi di Terminal Tipe B Palabuhanratu.

c. Tarif

Memberikan informasi mengenai tarif transportasi di Terminal Tipe B Palabuhanratu.

2) Layanan Pengaduan

Pengelola terminal mempermudah calon penumpang untuk mendapatkan layanan pengaduan secara mudah.

f. Aktivitas Pendukung

1) Oprasional Terminal

Aktivitas ini meliputi melaksanakan penataan pelataran fasilitas penumpang, melaksanakan penyajian daftar rute perjalanan dan daftar tarif,

2) Tenaga Teknis

Yang bertugas membantu melaksanakan pengelolaan Terminal Tipe B Palabuhanratu sesuai dengan tugas dan tupoksinya.

\section{Business Architecture}

a. Arsitektur Aktivitas Bisnis yang Sedang Berjalan

Aktivitas bisnis yang sedang berjalan pada Terminal Tipe

B Palabuhanratu digambarkan menggunakan diagram Use Case seperti pada Gambar 6 berikut.

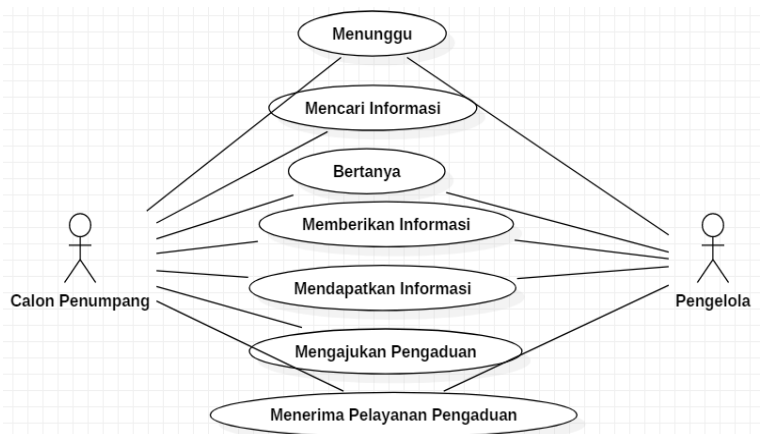

Gambar 6. Use Case Aktivitas Bisnis yang Sedang Berjalan

b. Arsitektur Aktivitas Bisnis yang Diusulkan

Aktivitas bisnis yang di usulkan pada Terminal Tipe B Palabuhanratu digambarkan menggunakan diagram Use Case seperti Gambar 7 berikut.

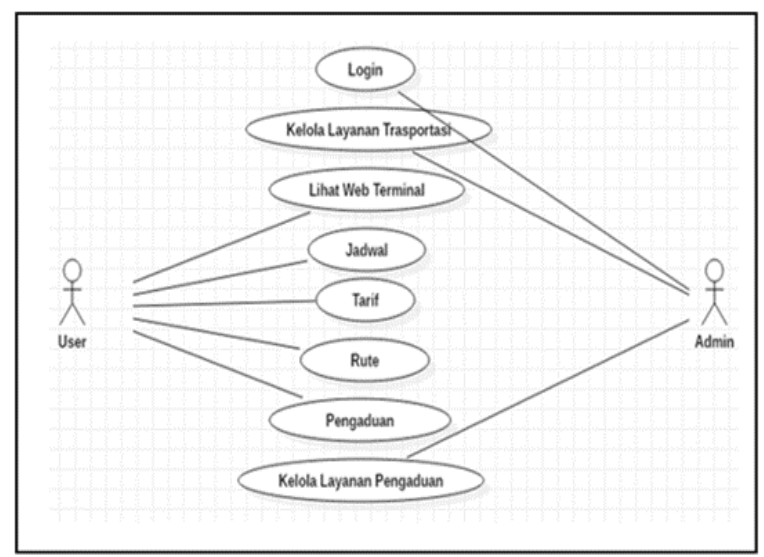

Gambar 7. Use Case Aktivitas Bisnis yang Diusulkan.

\section{Information System Architecture}

a. Arsitektur Data

Tahapan ini merupakan tahapan perancangan arsitektur data, Rancangan tersebut akan peneliti gambarkan dalam bentuk perancangan activity diagram dan database, berikut ini gambarannya:

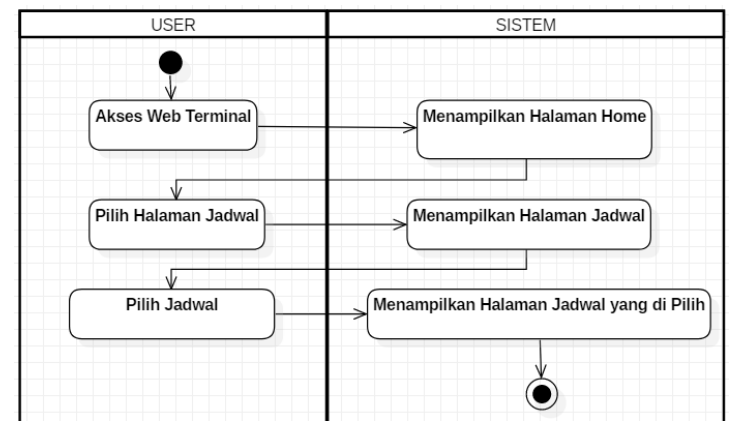

Gambar 8. Activity Diagram Jadwal 

Menggunakan Model TOGAF ADM (Studi Kasus: Terminal Tipe B Palabuhanratu)

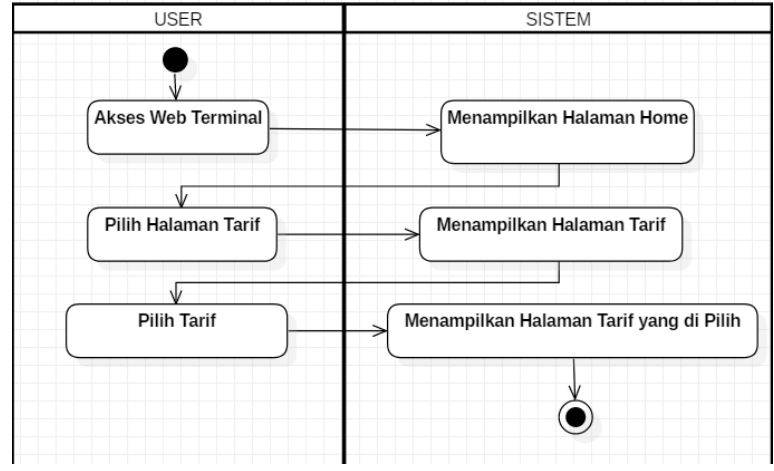

Gambar 9. Activity Diagram Tarif

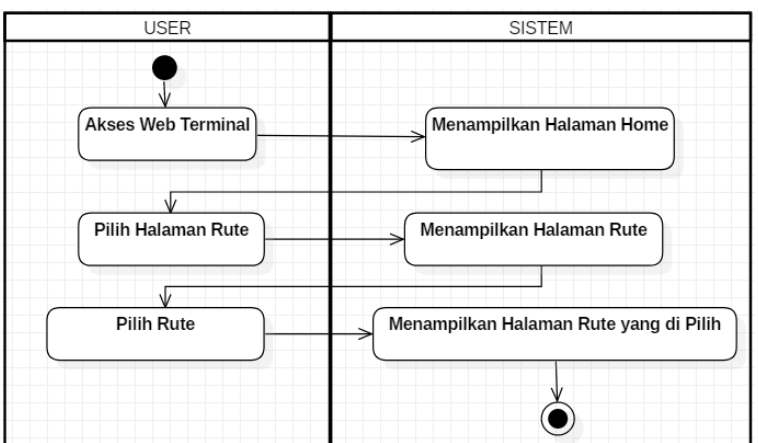

Gambar 10. Activity Diagram Rute

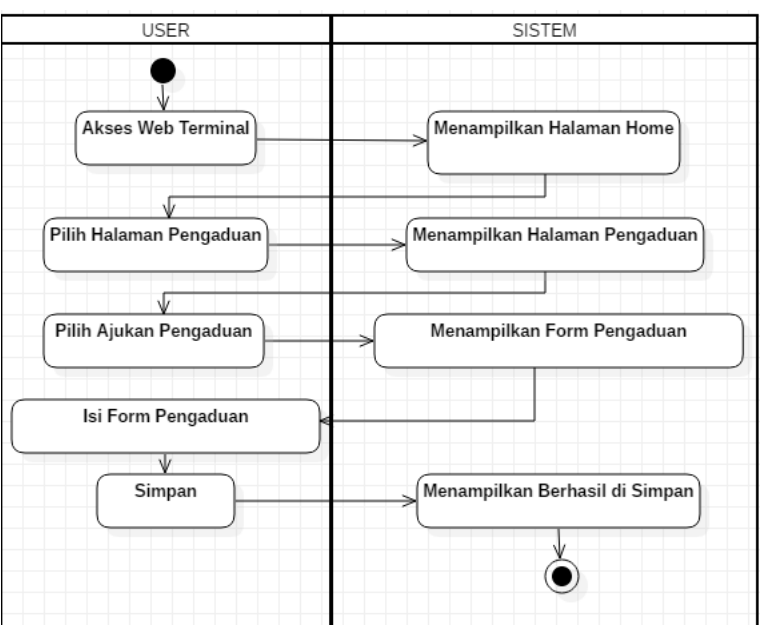

Gambar 11. Activity Diagram Pengaduan

Terdapat activity diagram jadwal, tarif rute dan pengaduan sepeerti pada Gambar 8, Gambar 9, Gambar 10, dan Gambar 11 di atas. Dimana user mengakses web terminal dan memilih fitur informasi yang di butuhkan seperti informasi jadwal, tarif, rute, dan pengaduan.

Selain itu juga terdapat activity diagram untuk login admin dengan memasukan username dan password untuk dapat masuk ke menu admin, dimana di dalam menu admin terdapat pilihan fitur pengelolaan layanan transportasi dan pengelolaan pengaduan, seperti pada Gambar 12, Gambar 13, dan Gambar 14 di bawah ini.

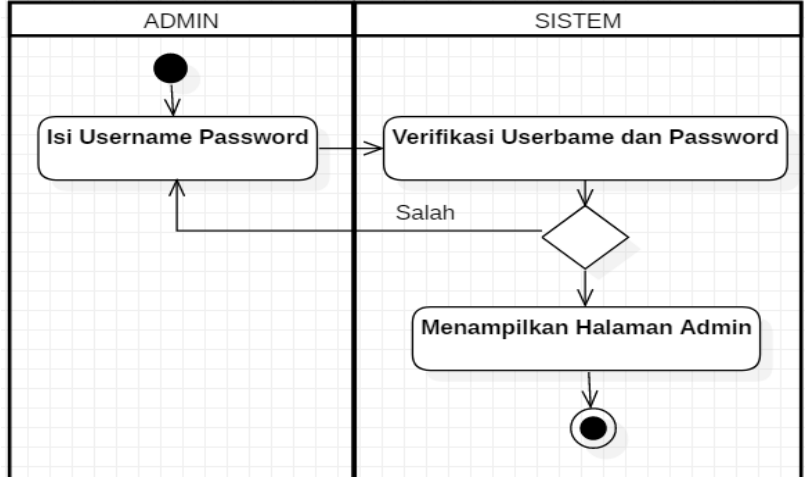

Gambar 12. Activity Diagram Login Admin

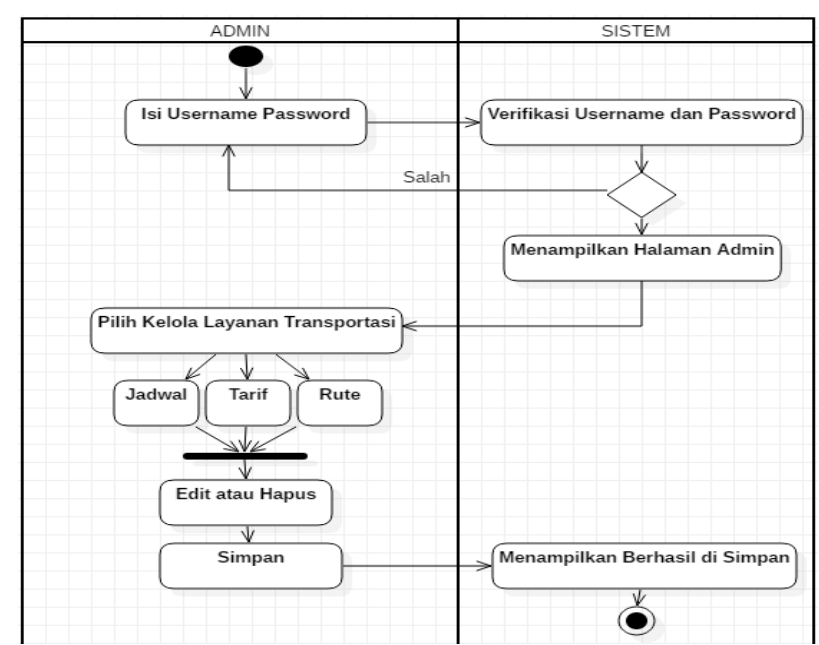

Gambar 13. Activity Diagram Kelola Layanan Transportasi

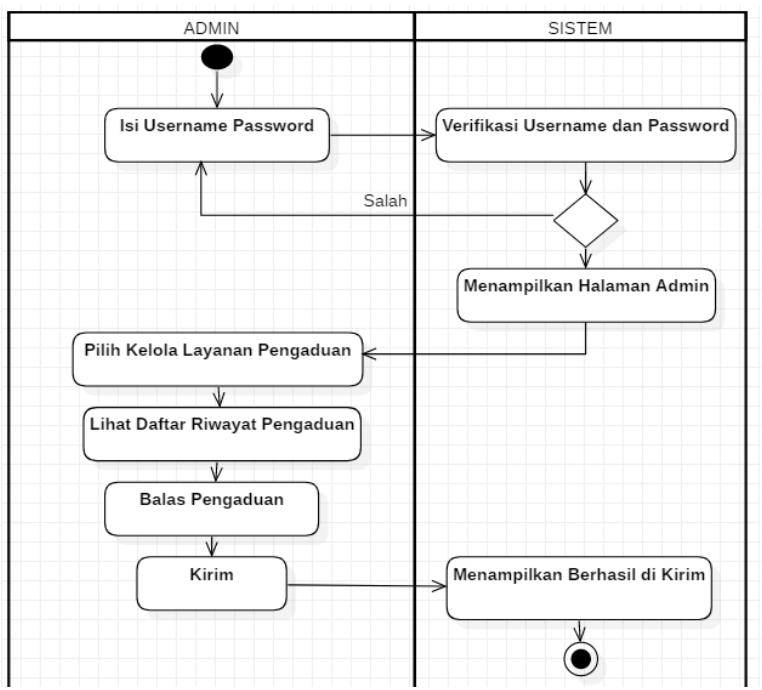

Gambar 14. Activity Diagram Kelola Layanan Pengaduan 


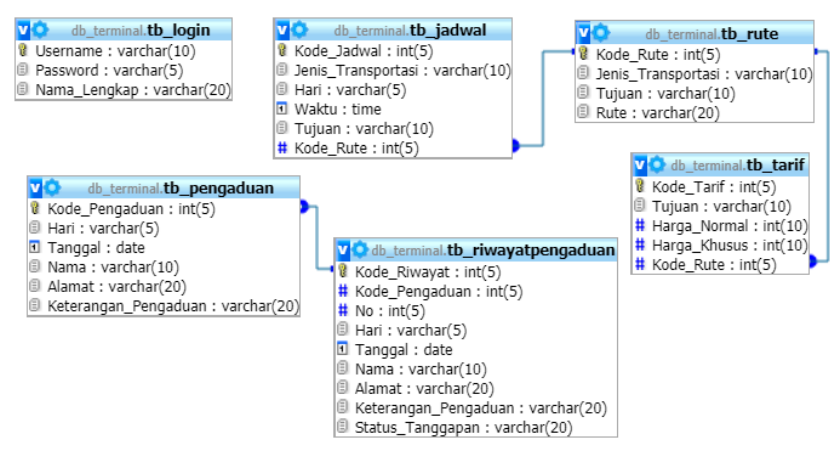

Gambar 15. Rancangan Database

Perancangan database pada Gambar 15 di atas digunakan untuk penyimpanan data dan relasi antar tabel pada sistem database. Yang akan di gunakan pengelola terminal untuk dapat menyelaraskan kebutuhan sistem yang akan di gunakan nantinya.

\section{b. Arsitektur Aplikasi}

Berikut merupakan gambaran perancangan katalog Aplikasi rancangan Sistem Informasi Terminal yang dapat di lihat pada Tabel 4.

Tabel 4. Rancangan Katalog Aplikasi

\begin{tabular}{lll}
\hline No & \multicolumn{1}{c}{ Proses } & \multicolumn{1}{c}{ Fitur Sistem } \\
\hline $\begin{array}{l}\text { Pengelolaan } \\
\text { menu sistem } \\
\text { informasi } \\
\text { terminal } \\
\text { dilakukan } \\
\text { oleh Admin }\end{array}$ & $\begin{array}{l}\text { Di dalamnya terdapat form Login, } \\
\text { Menu Admin, Layanan transportasi } \\
\text { mengenai jadwal, tarif, rute dan } \\
\text { Layanan Pengaduan }\end{array}$ \\
\hline 2. & User & $\begin{array}{l}\text { Di dalamnya terdapat: informasi } \\
\text { fasilitas, jadwal, rute, tarif, pengaduan } \\
\text { dan hubungi Kami }\end{array}$ \\
\hline 3. & Jadwal & $\begin{array}{l}\text { Menginformasikan jadawal } \\
\text { keberangkatan transportasi yang di } \\
\text { kelola di terminal }\end{array}$ \\
\hline 4. & Rute & $\begin{array}{l}\text { Menginformasikan tarif harga pada } \\
\text { transportasi yang di kelola di terminal }\end{array}$ \\
\hline 4. & Tarif & $\begin{array}{l}\text { Menginformasikan rute tujuan } \\
\text { transportasi yang di kelola di terminal }\end{array}$ \\
\hline & & $\begin{array}{l}\text { User dapat mengajukan pengaduan } \\
\text { atau keluhan atas ketidaknyamanan } \\
\text { atau ketidakpuasan pelayanan yang } \\
\text { diberikan. Dan } \text { user juga dapat } \\
\text { melihat riwayat pengaduannya }\end{array}$ \\
5. & $\begin{array}{l}\text { Layanan } \\
\text { Pengaduan }\end{array}$ & $\begin{array}{l}\text { Terdapat } \text { form yang berisikan } \\
\text { username dan } \text { password }\end{array}$ \\
\hline Login & & \\
\hline
\end{tabular}

\section{Technology Architecture \\ a. Arsitektur Jaringan}

Gambar 16 berikut ini merupakan gambaran dari Arsitektur jaringan usulan pada Terminal Tipe B Palabuhanratu.

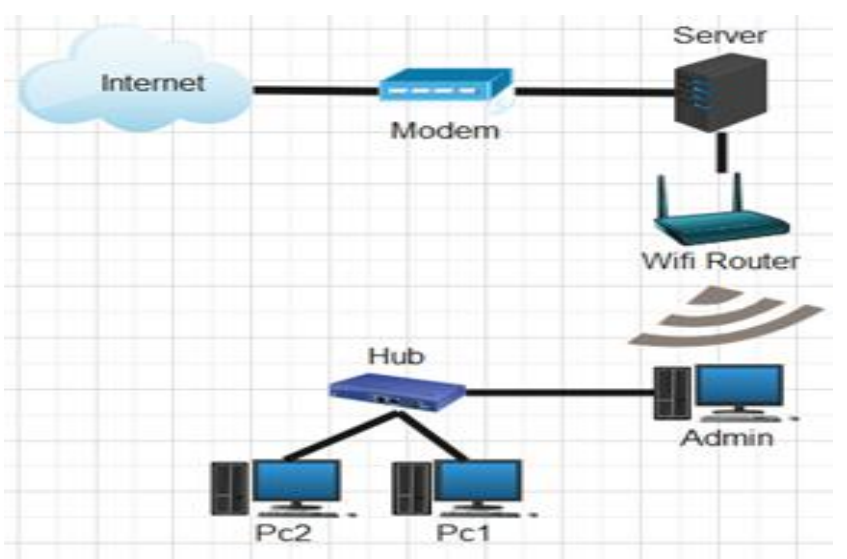

Gambar 16. Arsitektur Jaringan

b. Spesifikasi Hardware dan Software

Tahapan ini dimana melakukan usulan mengenai perangkat keras dan perangkat lunak untuk mendukung arsitektur teknologi yang di usulkan.

- Software (Perangkat Lunak)

Tabel 5. Usulan Software

\begin{tabular}{ll}
\hline \multicolumn{1}{c}{ Software } & \multicolumn{1}{c}{ Spesifikasi } \\
\hline Operating System & Window 10 Home( 64 bit) \\
\hline Coding & PHP, JavaScript \\
\hline DBMS & MYSQL \\
\hline Web Browser & Google Chrome \\
\hline Microsoft Office & 2019 \\
\hline
\end{tabular}

- Hardware (Perangkat Keras)

Tabel 6. Usulan Hardware

\begin{tabular}{ll}
\hline \multicolumn{1}{c}{ Hardware } & \multicolumn{1}{c}{ Spesifikasi } \\
\hline CPU & AMD Core i5 \\
\hline Processor & Intel Core i5 \\
& 8400T(1.70nGhzmup to \\
& $3.30 \mathrm{GHz}, 9 \mathrm{MB}$ Cache $)$ \\
\hline RAM & $28 \mathrm{~GB}$ \\
\hline Input Device & Mouse, Keyboard \\
\hline Output Device & Monitor LCD \\
\hline
\end{tabular}

\subsection{Hasil Blueprint Perancangan Enterprise Architecture (EA)}

Hasil perancangan enterprise architecture Terminal Tipe B Palabuhanratu ini berupa blueprint layanan transportasi mengenai jadwal, tarif rute dan layanan pengaduan, selain itu menghasilkan arsitektur sistem informasi dan arsitektur teknologi guna untuk menyelaraskan strategi bisnis yang dibutuhkan oleh Terminal Tipe B Palabuhanratu, seperti Gambar 17 di bawah ini. 


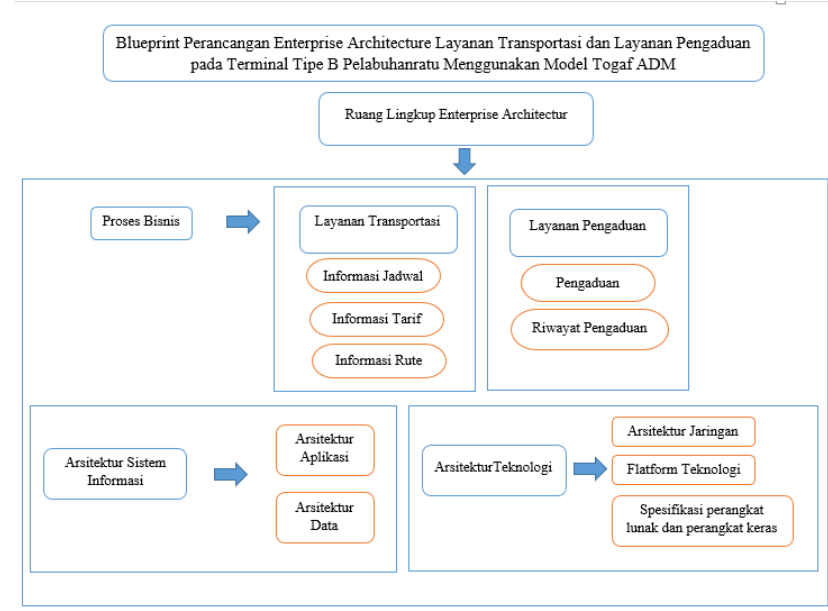

Gambar 17. Blueprint Perancangan EA Sistem Informasi Terminal

\section{IV.KESIMPULAN DAN SARAN}

\subsection{Kesimpulan}

Bahwasanya di Terminal Tipe B Palabuhanratu belum memiliki perancangan arsitektur. Maka dari itu peneliti membuat suatu perancangan enterprise architecture dengan menggunakan model TOGAF ADM supaya dapat menyelaraskan strategi bisnis untuk meningkatkan pelayanan pada Terminal Tipe B Palabuhanratu. Minimnya pemanfaatan teknologi pada terminal palabuhanratu membuat pengelola terminal terbatas dalam memberikan informasi kepada masyarakta atau calon penumpang, Umumnya dalam informasi mengenai pelayanan transportasi dan layanan pengaduan.

Hasil dari perancangan Enterprise Architecture Terminal Tipe B Palabuharatu ini berupa sebuah Blueprint (Cetak Biru) pelayanan Transportasi mengenai informasi jadwal, tarif, rute dan Layanan Pengaduan, selain itu menghasilkan Arsitektur Sistem Informasi dan Arsitektur Teknologi untuk menyelaraskan strategis bisnisnya, dengan menerapkan fasefase dari arsitektur model TOGAF ADM, yang nantinya dapat digunakan sebagai acuan dalam implementasi di buatnya suatu Sistem Informasi dan Teknologi Informasi yang saling terintegrasi dan selaras dengan kebutuhan pada Terminal Tipe B Palabuhanratu, sehingga pengelola terminal dapat meningkatkan pelayanan informasi terhadap masyarakat.

\subsection{Saran}

Pada penelitian selanjutnya, dalam penerapan fase-fase model TOGAF ADM di harapkan untuk dapat menerapkan semua fase yang ada pada tahapan TOGAF. Dimana peneliti disini hanya menerapkan sampai fase Technology Architecture, supaya pengimplementasian arsitektur pada perusahaan menjadi lebih mudah. Adanya hasil Blueprint Perancangan Enterprise Achitecture Layanan Transportasi mengenai jadwal, rute, tariff dan layanan Pengaduan pada Terminal Tipe B Palabuhanratu diharapkan dapat digunakan sebahai acuan dalam implementasi di buatnya suatu Sistem Informasi dan Teknologi Informasi yang saling terintegrasi dan selaras dengan kebutuhan bisnis pada Terminal Tipe B Palabuhanratu.

\section{REFERENSI}

[1] Tingginehe, A.M., Waani, J.O. \& Wuisang, C.E.V. (2019). Perencanaan Pariwisata Hijau di Distrik Roon Kabupaten Teluk Wondama, Papua Barat. Jurnal Spasial, Vol. 6(2), pp. 511-520.

[2] Sutiawan, A., Marlianti, R.S., Kareksi, S.T. \& Saepudin, S. (2020). Perancangan Enterprise Architecture Pendaftaran Uji Kir Menggunakan FEAF di DISHUB Kab. Sukabumi. Prosiding Seminar Nasional Informatika (SEMNASIF).

[3] Sastradipraja, C.K., Gustian, D. \& Antadipura, S.S. ( "Perencanaan Strategi Sistem Informasi Penjualan Menggunakan Pendekatan TOGAF Adm (Studi Kasus : Three Sister's House Of Beauty). @is The Best : Accounting Information Systems and Information Technology Business Enterprise, Vol. 4(2), pp. 136-150. DOI: 10.34010/aisthebest.v4i02.2332.

[4] Suseno, A., Arifin, J. \& Sutrisno, S. (2020). Analisis Value Chain Management pada Usaha Mikro Kecil dan Menengah di Indonesia. Go-Integratif Jurnal Teknik Sistem dan Industri, Vol. 1(1), pp. 24-33. DOI: 10.35261/gijtsi.v1i01.4294.

[5] Huda, M. (2018). Evaluasi Usability Website STIE Putra Bangsa Sebagai Media Informasi Perguruan Tinggi. Jurnal Ekonomi Dan Teknik Informatika, Vol. 6(2), pp. 9-19.

[6] Shafwan, R. (2020). Pendalaman Karakter Siswa-Siswi Dalam Ekstrakurikuler Teater Disma Negeri 1 Alalak Menggunakan Olah Sukma. DESKOVI: Art and Design Journal, Vol. 3(1), pp. 59-64. DOI: 10.51804/deskovi.v3i1.728.

[7] Fasya, S. \& Wasta, A. (2020). Peran dan Fungsi Kesenian Calung Tarawangsa di Desa Parung Kecamatan Cibalong Kabupaten Tasikmalaya. Magelaran: Jurnal Pendidikan Seni, Vol. 3(1), pp. 121128.

[8] Larasati, H. \& Masripah, S. (2017). Analisa Dan Perancangan Sistem Informasi Pembelian GRC Dengan Metode Waterfall. Jurnal Pilar Nusa Mandiri, Vol. 13(2), pp. 193-198.

[9] Dellarosawati, M. (2019). Riset Teknologi Finansial untuk UMKM dalam Menunjang Laporan Keuangan. Jurnal Akuntansi dan Keuangan Methodist, Vol. 3(1), pp. 33-38.

[10] Rusdi, I., Mulyani, A.S. \& Herlina, I. (2020). Rancang Bangun Sistem Informasi Pembelian Pada CV. Cimanggis Jaya Depok. Jurnal Akrab Juara, Vol. 5(2), pp. 180-197. 